\title{
Cicatricial Ectropion Correction in the Inferior Eyelid with Cartilaginous Tissue Graft: Case Report
}

\author{
Corrección de Ectropión Cicatricial en el Párpado Inferior \\ con Injerto Libre de Cartílago. Reporte de un Caso
}

\begin{abstract}
Aline Monise Sebastiani*; Guilherme dos Santos Trento*; Fernando Antonini*; Leandro Eduardo Kluppel**; Rafaela Scariot**; Delson João da Costa** \& Nelson Luis Barbosa Rebellato***
\end{abstract}

SEBASTIANI, A., M.; TRENTO, G., S.; ANTONINI, F.; KÜPPEL, L., E.; SCARIOT, R.; DA COSTA, D., J.; REBELLATO, N., L., B. Cicatricial ectropion correction in inferior eyelid with cartilaginous tissue graft: Case report. Int. J. Med. Surg. Sci., 1(3):217-222, 2014.

SUMMARY: Transcutaneous approaches of the lower eyelid are commonly used to provide adequate exposure of the orbital floor and zygomaticomaxillary suture during treatment of facial fractures. Cicatricial ectropion is a rare complication that results in a shortened eyelid. This condition can be temporary in some cases but when it is permanent it must be surgically corrected, aiming to restore function, improve the aesthetical outcomes and to prevent ophthalmological disorders such as epiphora and corneal ulceration. The present study describes a novel surgical approach, associated with a concomitant cartilaginous graft, to treat severe lower eyelid ectropion resultant from a previously performed subtarsal incision.

KEY WORDS: Ectropion; Postoperative complications; Cartilage; Nasal septum.

\section{INTRODUCTION}

Ectropion is the retraction or eversion of the ciliary margin in the opposite direction of the eyeball and can occur in different degrees, just as a point eversion with small scleral show or with full rotation of the eyelid with the conjunctival surface facing out (Eliasoph, 2005). Moreover, it can be classified as congenital or acquired. The latter can be subdivided into involutional, cicatricial, mechanical and paralytic (Matayoshi et al., 2004). Cicatricial ectropion is the result of shortening of the anterior lamella (Veloso et al., 2006) and is a complication associated with transcutaneous incisions ofthe lower eyelid. As a result of the lack of contact between the eyeball and the everted lid, eyelid glands become ectatic accumulating their secretions. Consequently, keratitis can occur culminating in corneal ulcer, chronic conjunctivitis, blepharitis and hordeolum. Exposure of the tarsal conjunctiva can lead to hypertrophy and keratinization of the conjunctival mucosa. Furthermore, increased scleralshow is unaesthetic and is frequently associated with inadequate drainage of tears and excessive dryness (Schaudig, 2012).

When this condition is permanent, it must be corrected surgically. Surgical treatment of severe ectropion aims functional and aesthetic restoration, preventing ophthalmological complications and improving facial appearance. Among various techniques for correction of ectropion (Eliasoph; Goel et al., 2013; Garza et al., 2012) the use of an autogenous cartilage graft to provide support to the eyelid has been described (Carraway \& O'Loughlin, 1994; Krastionova et al., 2002).

* Resident, Department of Oral and Maxillofacial Surgery at Federal University of Paraná (UFPR), Curitiba, Brasil.

** Associated Professor, Department of Oral and Maxillofacial Surgery at Federal University of Paraná (UFPR), Curitiba, Brasil.

${ }^{* * *}$ Chairman, Department of Oral and Maxillofacial Surgery at Federal University of Paraná (UFPR), Curitiba, Brasil. 
The aim of this study is to demonstrate a novel surgical technique for cicatricial ectropion correction after a subciliary incision, through grafting of cartilaginous tissue from the nasal septum.

\section{CASE REPORT}

A 51 years old, leucoderma, male patient presenting the left zygomatic-orbital complex fractured, reporting being a victim of physical agression (Figs. 1 and 2). He underwent surgery under general anesthesia for fracture reduction through intra-oral, supraciliar and subtarsal incisions.

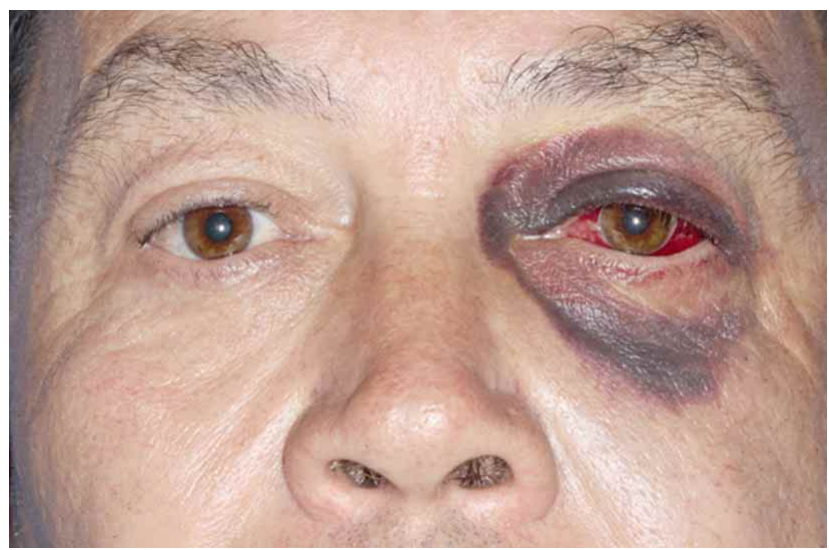

Fig. 1. Admission to Hospital with orbital fracture.

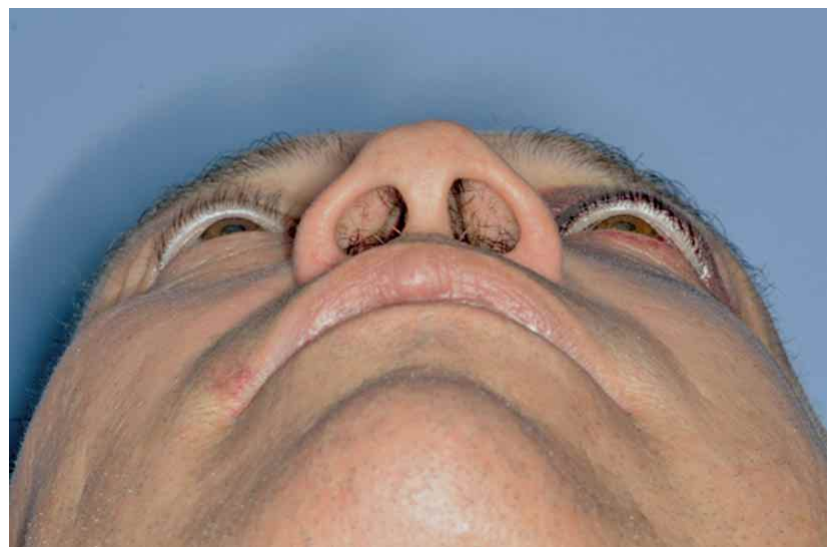

Fig. 2. Deficencie en vertex projection with a low level in the left side.

During postoperative follow-up, gradual eversion of the inferior eyelid margin was observed. The patient was instructed to perform massages in the region and was prescribed ophtalmological ointment to prevent ocular dryness.

After three months of follow-up, the patient showed facial symmetry with good zygomatic projection demonstrating correct fracture reduction. However, clinical signs and symptoms of permanent ectropion were evident (Fig. 3). At this time, surgical correction was indicated.

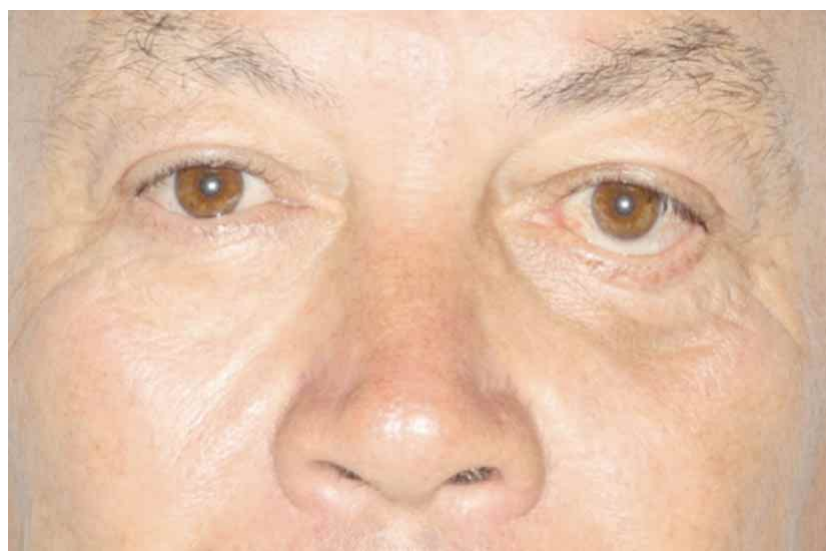

Fig. 3. Ectropion after subtarsal approach.

\section{Surgical Technique}

Under general anesthesia, a 4cm maxillary vestibule incision was performed to expose the nasal floor and septum. After dissection, the anterior portion of the cartilaginous septum was clamped and removed $(2 \times 1 \mathrm{~cm})$ with the aid of a Metzenbaum scissor. Simple continuous suture was performed, using absorbable thread (Vicryl 3-0). After that, a left subtarsal incision was performed (Fig. 4). Undermining just anterior to the tarsal plate created a "pocket in the lower eyelid. The graft was shaped like a semi-circle, mimicking the lid (Fig. 5), and properly positioned and sutured in the tarsal plate extremities (Figs. 6 and 7). Suture was performed by planes with 5-0 poliglactine thread and later intra-dermal suture with 6-0 mononylon (Fig. 8).

Twelve months after the grafting procedure on the left inferior eyelid, the patient had adequate eyelid anatomy and function performing complete sealing of the eyelids and no aesthetic complaints (Fig. 9). 


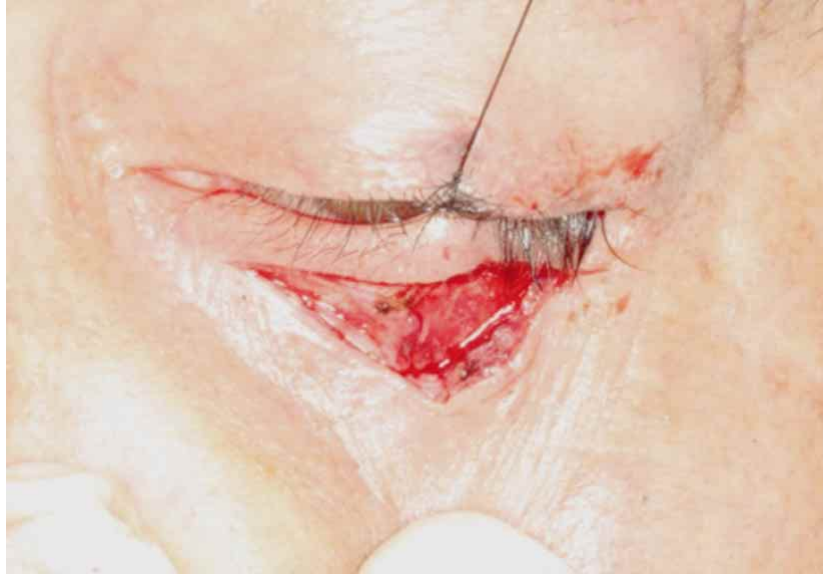

Fig. 4. Surgical approach to make a cartilage free graft.

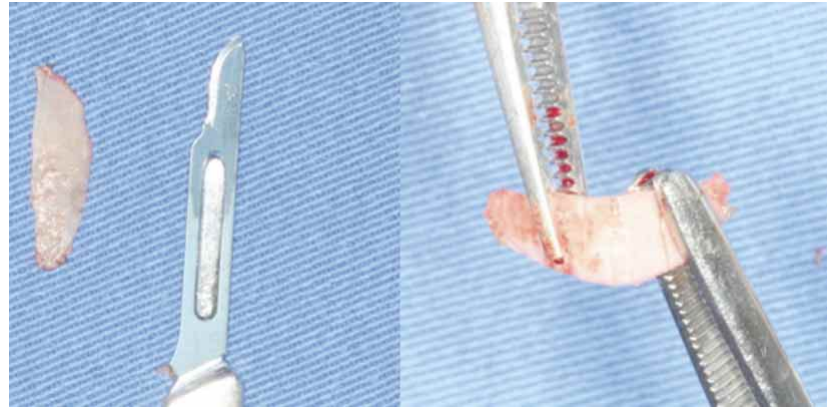

Fig. 5. Cartilage from nasal area.

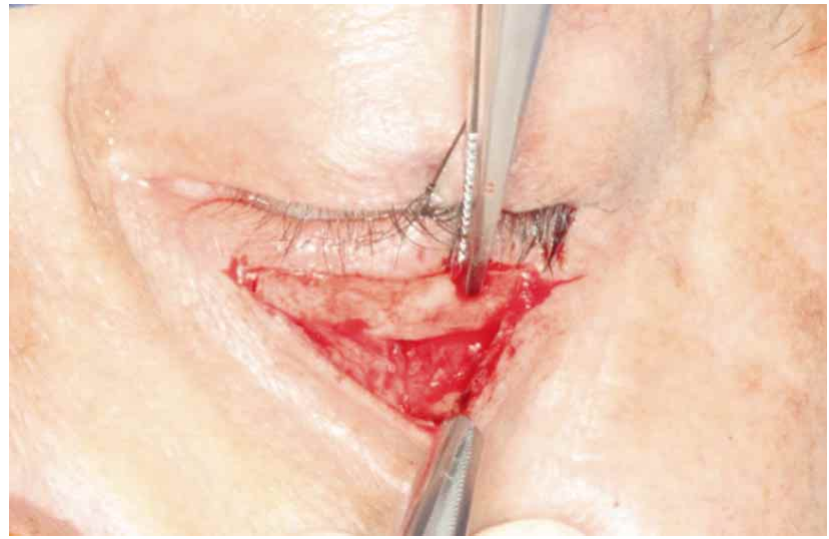

Fig. 6. Cartilege free graft put into the low eyeled.

\section{DISCUSSION}

Currently, there is a great discussion about the advantages and disadvantages of transcutaneous and transconjunctival access to the orbital floor and infraorbital rim. Ectropion is a complication that develops temporarily at least in $28 \%$ to $42 \%$ of the transcutaneous

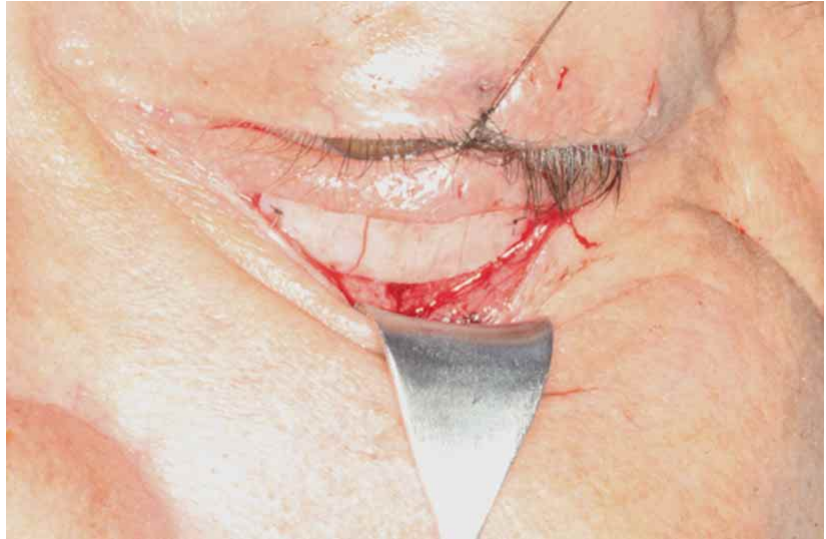

Fig. 7. Graft sustained over the tarsal plate.

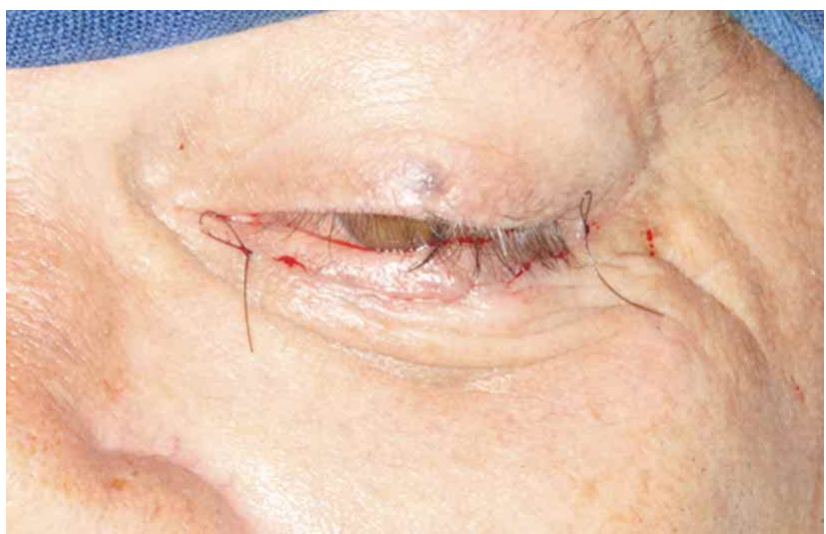

Fig. 8. intraoperative result after suture.

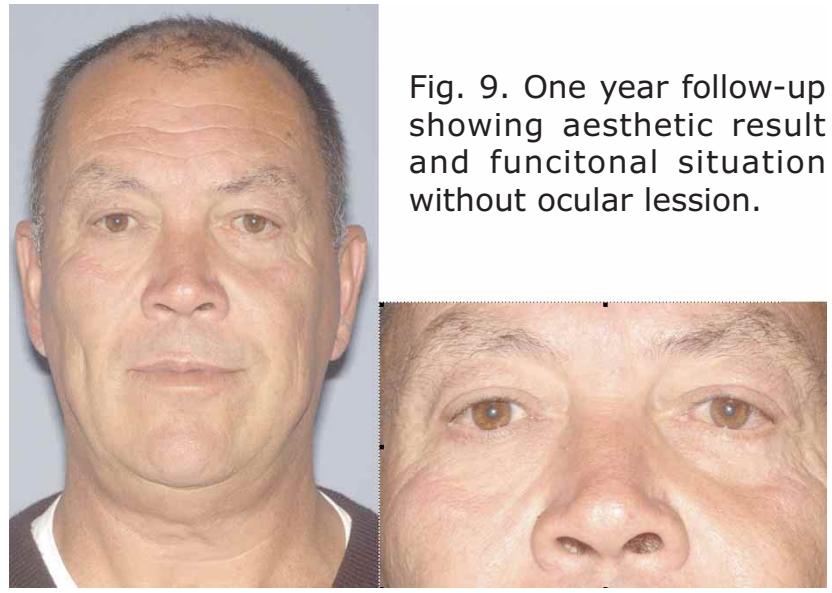

approaches to the orbital floor whereas the transconjunctival approach has been reported in less than $0.5 \% 9$.

For Wilson \& Elis III (2006), transcutaneous incisions provide the surgeon 
SebAStiAnI, A., M.; TRENTO, G., S.; ANTONINI, F.; KÜPPEL, L., E.; SCARIOT, R.; DA COSTA, D., J.; REBELLATO, N., L., B. Cicatricial ectropion correction in inferior eyelid with cartilaginous tissue graft: Case report. Int. J. Med. Surg. SCi., 1(3):217-222, 2014.

adequate exposure without violating the lateral canthal ligament. Holtmann et al., argue that lateral canthotomy offers adequate surgical exposure in transconjunctival access but invades the skin, and the main objective of using this incision is hidden scar. Lateral canthotomy is often used during antransconjunctival approach (56\% to $83 \%$ ). From researchs about blepharoplasty (Spira, 1977; Spira, 1978; Rees \& Tabbal, 1981), the literature shows that transcutaneous approaches have the advantage of reducing the chances of injury to the ocular globe or cornea and are less risky to the deeper orbital structures.

Several authors (Rohrich; Feldman et al., 2011; Bahr et al., 1992) agree that subtarsal approach in comparison with subciliary approach produce lower risk of vertical shortening of the inferior eyelid and decreases the incidence of scleral show and ectropion. According to Bahr et al. this approach provides the most direct and fastest way to the orbital floor compared to others transcutaneous approaches.

Patients presenting inferior eyelid retraction have in common the absence of eyelid support causing an imbalance in the forces that control their position. Common causes of ectropion involve direct lacerating injuries since when the laceration reaches deep plans intraoperatively, thermal burns and chronic sun exposure, and postoperative after blepharoplasty. The pathogenesis of retraction is multifactorial. However, the main factors that cause retraction are deficient anterior lamella or skin, scar retraction of the middle lamella caused by local inflammation and fibrosis after incision, and ligamentous laxity. The vertical scar retraction of the middle lamella leads to vertical entrainment of the eyelid retractor muscles leading to lower shrinkage with or without eversion of the ciliary margin. As the septum retracts, it shortens the distance between the ciliary margin and the inferior orbital arc (Bahr et al.). Presence of pellets and devitalized tissue, loss of substance without replacement, scarification of the eyelids, sutures poorly made, neglect of post-operative care are some factors that contribute to the occurrence of ectropion after transcutaneous access (Timoteo et al., 2009).
Evaluation of post-operative care of the patient, consistent knowledge of periorbital anatomy, proper use of existing surgical resources, concern with function and fashion are some variables that prevent the development of ectropion after surgery (Kanski, 2004).

The exposure arising from chronic ectropion may result in keratinization of the conjunctiva which contributes to ocular irritation and can lead to vision loss. There are specialized structures in the eyelids promoting protection to the eyes, numerous oils, mucus and aqueous producing-tears glands present within the mucosal lining of the tarsus - superior and inferior eyelid conjunctiva. The blinking of the eyelids distributes this complex forming a film on the surface of the eyes (Bahr et al., 1992). According to Eliasoph, temporary palliative treatments are essential for the protection of the cornea.He recommends the use of artificial tears, ointments, eye protectors that retain moisture and even temporary tarsorrhaphy, among others. The patient presented in this report was followed for three months performing massages on the inferior eyelid and making use of artificial tears, as long as no improvement was observed, was considered a permanent ectropion opting for surgical intervention to correction.

Treatment with sutures, skin grafts and even rotation flaps in the most serious cases of ectropion are described in the literature (Eliasoph; Goel et al.; Garza et al.) but is confident that to return the appropriate eyelid anatomy and function is necessary restore the inferior eyelid intrinsic support which can be accomplished by cartilaginous grafts. Carraway \& O'Loughlin described a technique using nasal septum cartilage to provide support for the inferior eyelid structures attenuated, emphasizing the importance of making the release of the deep scar of the capsuloligamentous eyelid fascia on the dissection for graft implantation and thus achieve ideal reconstruction. About 20 eyelids, for a period of 12 years underwent reconstruction of severe ectropion using this technique. Reconstructive satisfactory results with minimal complications were reported. 
SEBASTIANI, A., M.; TRENTO, G., S.; ANTONINI, F.; KÜPPEL, L., E.; SCARIOT, R.; DA COSTA, D., J.; REBELLATO, N., L., B. Cicatricial ectropion correction in inferior eyelid with cartilaginous tissue graft: Case report. Int. J. Med. Surg. Sci., 1(3):217-222, 2014.

Krastinova et al. also described a technique of cartilage tissue grafting for ectropion correction using auricular concha as donor area, also reporting success of the technique.In this case, we opted for the removal of cartilaginous tissue as graft. Postoperative recovery was uneventful with the return of the appropriate eyelid anatomy and function.

\section{CONCLUSION}

The technique of cartilage tissue grafting from the nasal septum in inferior eyelid is a simple, safe and effective technique for the resolution of postoperative permanent ectropion of the inferior eyelid.

SEBASTIANI, A., M.; TRENTO, G., S.; ANTONINI, F.; KÜPPEL, L., E.; SCARIOT, R.; DA COSTA, D., J.; REBELLATO, N., L., B. Corrección de ectropión cicatricial en el párpado inferior con injerto libre de cartílago. Reporte de un caso. Int. J. Med. Surg. Sci, 1(3):217-222, 2014.

RESUMEN: El acceso transcutáneo del párpado inferior se utiliza comúnmente para proporcionar una exposición adecuada al piso de la órbita y la sutura zygomaticomaxilar durante el tratamiento de las fracturas faciales. Ectropión cicatricial es una rara complicación resultante de la reducción del párpado. Esta condición puede ser temporal en alguns casos, pero cuando es permanente debe ser corregida quirúrgicamente con el objetivo de restaurar la función, mejorar los resultados estéticos y para prevenir transtornos oftalmológicos tales como epífora y ulceración de la córnea. El presente estudio describe un nuevo abordage quirúrgico, asociado con el injerto cartilaginoso concomitante, para tratar un grave ectropión del párpado inferior resultante de la incisión subtarsal realizado anterior.

PALABRAS CLAVE: Ectropión; Complicaciones postoperatorias; Cartílago; Tabique nasal

\section{REFERENCES}

Bähr, W.; Bagambisa, F. B.; Schlegel, G. \& Schilli, W. Comparison of transcutaneous incisions used for exposure of the infraorbital rim and orbital floor: A retrospective study. Plast. Reconstr. Surg., 90(4): 585-91, 1992.

Carraway, J. H. \& O'Loughlin, K. C. The use of nasal septal cartilage grafts in lower eyelid reconstruction for ectropion. Oper. Tech. Plast. Reconstr. Surg., 1(3):127-35, 1994.

Eliasoph, I. Current Techniques of entropion and ectropion correction. Otolaryngol. Clin. North Am., 38(5):903-19, 2005.

Feldman, E. M.; Bruner, T. W.; Sharabi, S. E.; Koshy, J. C. \& Hollier, L. H. Jr. The subtarsal incision: Where should it be placed? Oral Maxillofac. Surg., 69(9):2419-23, 2011.

Garza, R. M.; Lee, G. K. \& Press, B. H. Tarsal ectropion repair and lower blepharoplasty: A case report and review of literature. J. Plast. Reconstr. Aesthet. Surg., 65(2):249-51, 2012.

Goel, R.; Kamal, S.; Bodh, S. A.; Kumar, S. ; Kishore, J.; Malik, K. P.; Singh, M. \& Bansal, S. Lower eyelid suspension using polypropylene suture for the correction of punctual ectropion. J. Craniomaxillofac. Surg., 41(7):111-6, 2013.

Holtmann, B.; Wray, R. C. \& Little, A.G. A randomized comparison of four incisions for orbital fractures. Plast. Reconstr. Surg., 67(6):731-7, 1981.

Kanski, J. J. Oftalmología Clínica. $5^{\text {a }}$ ed. Elsevier, Rio de Janeiro, 2004.

Krastionova, D.; Franchi, G.; Kelly, M. B. \& Chabolle, F. Rehabilitation of the paralysed or lax lower eyelid using a graft of conchal cartilage. Br. J. Plast. Surg., 55(1):12-9, 2002.

Matayoshi, S.; Forno, E. A. \& Moura, E. M. Ectrópio In: Matayoshi, S.; Forno, E. A. \& Moura, E. M. Manual de cirurgia plástica ocular. São Paulo, Roca, 2004. p.67-77.

Rees, T. D. \& Tabbal, N. Lower blepharoplasty: With emphasis on the orbicularis muscle. Clin. Plast. Surg., 8(4):643-62, 1981.

Rohrich, R. J.; Janis, J. E. \& Adams, W. P. Jr. Subciliary versus subtarsal approaches to orbitozygomatic fractures. Plast. Reconstr. Surg., 111(5):170814, 2003. 
SEbAStIANI, A., M.; TRENTO, G., S.; ANTONINI, F.; KÜPPEL, L., E.; SCARIOT, R.; DA COSTA, D., J.; REBELLATO, N., L., B. Cicatricial ectropion correction in inferior eyelid with cartilaginous tissue graft: Case report. Int. J. Med. Surg. Sci., 1(3):217-222, 2014.

Schaudig, U. H. Eyelid malposition: Entropion and Ectropion. In: Spaeth, G. L.; Danesh-Meyer, H. V.; Goldberg, I. \& Kampik, A. Ophthalmic Surgery, $4^{\text {th }}$ ed. Barcelona, Elsevier, 2012. pp.326-39.

Spira, M. Lower blepharoplasty: A clinical study. Plast. Reconstr. Surg., 59(1):35-8, 1977.

Spira, M. Blepharoplasty. Clin. Plast. Surg., 5(1):121$37,1978$.

Timoteo, C. A.; Chagas, J. F.; Rapoport, A. \& Denardin, O. V. Avaliação da abordagem palpebral subtarsal no tratamento cirúrgico das fraturas zigomáticoorbitais. Rev. Col. Bras. Cir., 36(5):382-91, 2009.

Veloso, C. E.; Schellini, S. A.; Padovani, C. R. \& Padovani, C. R. Ectrópio palpebral: características e relação com alterações óculo-palpebrais. Rev. Bras. Oftalmol., 65(3):147-51, 2006.

Wilson, S. \& Ellis, E. 3rd. Surgical Approaches to the infraorbital rim and orbital floor: the case for the subtarsal approach. J. Oral Maxillofac. Surg., 64(1):104-7, 2006.
Coorespondence to:

Dr. Aline Monise Sebastiani

Presidente Affonso Camargo Avenue

2625. Cristo Rei

Curitiba - Paraná

ZIPCODE: 80050370

BRASIL

Email: sebastiani.aline@gmail.com

Received: 15-08-2014

Accepted: 16-09-2014 